\title{
Children's Drawing in the Context of the Visual Language of New Media. Research Report
}

\author{
Bernadeta Didkowska \\ Nicolaus Copernicus University in Toruń, Poland \\ E-mail address: bedid@poczta.onet.pl
}

\section{ARTICLE INFO}

\section{Keywords:}

Children's drawing

New media

Visual language

Mediasphere

Drawing abilities

\section{Article history:}

Received 23 Febuary 2016

Received in revised form 11 April 2016

Accepted 11 April 2016

ISSN: 2354-0036

DOI: 10.1515/ctra-2016-0004

\section{A B STRACT}

The present time is a period of dynamic development of new media, which should be accompanied by a more profound reflection over their impact on human development. The research on the impact of new media on children seems to be important as children become increasingly exposed to the virtual world, at the same time exploring reality. The time and commitment with which they "absorb" media images is bound to take its toll on a child's psyche, which manifests itself in the imaging. The article presents the research on drawing activity of children from 3 to 12 years old in the context of changes occurring in these activities brought about by the visual language of new media. The fact that this extensive research has been carried out over an interval of 10 years (in 2004 I carried out an analysis of 4180 drawings of children and youth aged 3 to 18 years, while in the study repeated in 2014 I examined 2134 drawings of children aged 3 to 12 years), makes it possible to compare the results of the two studies, and also to confront them with descriptions of children's drawings found in the specialized literature. In this way, the obtained characteristics may be referred to the visual language used to construct the new media image. Qualitative and quantitative analyses, as well as a comparison of the results, have allowed not only changes in the children's drawing activities to be determined, but also indicate the direction of these changes. For the research, it was also important to find arguments in favour of media education with reference to visual education and defined as training, that pertains to the entire contemporary iconosphere.

The subject of the presented research focuses on children's drawing activity perceived as a form of activity indispensable for the appropriate development of every human being. A contemporary child, right from the earliest years of his or her life, becomes a participant 
of the mediasphere. ${ }^{1}$ For this reason, the main purpose of this research was to try to trace modifications emerging in the children's drawing activity under the influence of intense cultural changes caused by the dynamic development of new media. ${ }^{2}$ In the process of drawing, children are always likely to be influenced by preexisting pictorial representations such as illustrations, images in churches, museums or at exhibitions. Equally, children might ask adults to draw particular objects for them. However, never has the influx of extrinsic patterns, as Wallon (Wallon et al., 1993) defines them, been so strong, never have children been faced with such a massively available diversity of media images, "submerged" with representations provided by the new media. Changes occurring in children's drawings result from their intellectual development, knowledge, cognitive and perceptual processes, which nowadays are often conditioned by canons of world representations provided by the new media. Today, not only has understanding of art itself changed drastically, but the range of art forms available to a child has increased, due to current technological progress, the character of the visual material a young person has access to and the way he or she approaches it, which changes at an incredibly fast pace. As recently as in the seventies only black and white television was available, which broadcast little more than an hour-long programme for children. The end of the 20th century was characterized by the domination of cartoons and computer games, while the last decade has been dominated by the Internet, smartphones, tablets, etc. Time spent intensively absorbing media images is bound to take its toll on a child's psyche, which manifests itself in the imaging. It therefore seems both interesting and important to carry out research on the influence that the new media has on children who nowadays not only inhabit the real world but also continue their increasingly intense exploration of virtual reality. Their engagement in this world is described literally as „immersion” into the mass produced, widespread and deeply experienced imaginary world, often more alluring than real life. Children are capable of differentiating symbols on a computer keyboard before they even learn to read and the media often become their main source of information, experience and emotions. Meanwhile, the extensive research I conducted in the years 2002 2004 concerning the influence of electronic images on the drawings of children and youth aged 3 to 18 showed that external projection influenced changes in the drawing activity of a child more than expected. Thus it is worth emphasizing that according to many re-

\footnotetext{
${ }^{1}$ Tomasz Goban-Klas (2004) considers the mediasphere to be a peculiar spatial perception created nowadays by the media in a traditional approach, or by mass media (press, radio, television and film), as well as telecommunication media (telephones and Internet) and multimedia (CD-ROMs, video, virtual reality).

${ }^{2}$ Lev Manovich (2006) emphasizes that all new media are digital, irrespective of whether they were originally created by computer or are the final result of digitalisation of analogue artistic productions. Therefore, on the one hand, there are media such as the Internet, Web sites, computer multimedia, CD-ROMs and DVDs; on the other hand, graphics, moving images, sounds, texts converted into digital data.
} 
searchers "the intrinsic model (Luquet, 1927) ${ }^{3}$ constitutes a solid foundation, resistant to numerous influences" (Wallon et al., 1993). Therefore, children's drawings described nearly 100 years ago, their typical features and sequentiality remain just as pertinent now as they were in the past.

Rapid changes taking place in the last decade, mostly related to the development of new media and child's environment progress accompanied by new technology since birth, made me feel that tracing possible changes arising out of these new relations which were difficult to predict 10 years ago, was necessary. Therefore, in the years 2012-2014 I carried out a replication of the studies from $2004 .{ }^{4}$ Repetition of this procedure allowed me to compare the results of studies conducted at different periods, as well as making it possible to confront them with descriptions of children's drawings found in the specialized literature. The obtained characteristics could be referred to the visual language constructing the new media image. I considered possible changes between generations as non-significant (because this was an obvious result) but an important factor was that they occurred so quickly, already to be seen over ten years, in the life span of one generation, media images playing a meaningful role. I was therefore interested in examining whether during the last ten years it was possible to observe any changes in the drawing activity of a child aged 3 to 12 years that could be attributed to the impact of visual qualities constructing the language of the new media. Hence, the question of whether and to what extent the image of the world in the new media induces changes in the drawing activity of a child aged 3 to 12 years. Should this kind of influence be factual, would it be possible to determine its characteristics and developmental consequences?

\section{RESEARCH METHODS}

The research was conducted in randomly chosen kindergartens and schools in order to include children with different cognitive skills and specific (directional) abilities. In the kindergarten group (aged 3 to 6 years), the research was conducted under normal class conditions. Children were asked to make two drawings on a plain sheet of paper, using oil pastels - first of a human, then an animal figure, with no time limit imposed. In the group of school children (aged 7 to 12 years), the research was conducted during classes following a set of standardized instructions. Students were asked to make pencil drawings on prepared paper forms, thematically corresponding to four tasks from Gilbert A. Clark's Drawing Abilities Test (Clark, 1989), i.e.: House seen from across the street, Fast running

\footnotetext{
${ }^{3}$ The notion of an intrinsic model was introduced to the Polish literature by Stefan Szuman (1927/1990) who assumed that drawings of children aged 10 years or less were created on the basis of apperceptive material belonging to a category of the inner image of the object transformed into a concept or scheme.

${ }^{4}$ Detailed elaboration of the research results has been presented in the book: Didkowska, B. (2015). Rysunek dziecka w wieku od 3 do 12 lat a język wizualny nowych mediów [Drawings of children aged 3 to 12 in the context of visual language of the new media]. Toruń, Wydawnictwo Naukowe UMK
} 
silhouette, Playing with friends on the school playground, Fantastic drawing based on imagination (15 minutes to complete each task). The drawing topics suggested by Clark take into account personal preferences of children and youth; are comprehensible for students and offer the opportunity to refer to previous drawing analyses.

\section{Methods of analysis and obtained results}

I obtained 2134 drawings made by children aged 3 to 12 years, divided into groups based on the criteria of the child's gender and age. The obtained material was evaluated in terms of quality and quantity using the test of one-way or two-way analysis of variance (ANOVA) and Duncan's post-hoc test. Hence the importance of the material and visual qualities analysis, which could become a reference scheme both for drawings described by earlier researchers and for visual language propagated by the new media. Bearing in mind the evaluation criteria applied by Clark (1989) as well as Kościelecki's theory of form described in his book Współczesna koncepcja wychowania plastycznego (Kościelecki, 1975), I designed a specific method of analysis of the drawings. Since the topics of the drawings in this research were different for different ages of children, different methods for the analysis of the research material were applied in each case. Drawings obtained in 2004 and 2014 were analysed by the same method thus enabling detailed comparisons.

\section{Methods of evaluation used for the drawings of kindergarten children}

In order to analyze the obtained research material, suitable tables were designed, in which the analyzed drawings were qualified as: scribbles, cephalopods, schemes, patterns, types and transitions. Additionally, some drawings referred to existing real or media characters or patterns of an animal recognizable by its attributes. Bearing in mind the acceleration of development (Popek, 2010), it was necessary to extract the visual qualities, which in the specialized literature are ascribed to older children, thus tables focusing on the organization of the plane were designed. In each of the described tables, a column tagged as „others” was singled out for content and form qualities that had not been previously categorized and yet appeared in the children's drawings.

\section{Methods of evaluation used for the drawings of school children}

Given that the basic mark scale established by Clark (1989) was suitable for testing artistic abilities, which was not the objective of this research, it was necessary to design a specific method of analysis for the research material. This method would allow, on the one hand, the obtained material to be characterized and, on the other, to relate these characteristics to the ones described in the specialized literature, as well as to the characteristics of visual qualities appearing in the images of the new media. I considered that a quality that can be related to all of the children's drawings is a description of their con- 
tent and analysis of their artistic form. Assuming that the visual art language refers significantly to the new media language, while its general basic artistic qualities can simultaneously become a point of reference for the descriptions of the medial visual language, I focused on elements of the artistic form, such as space, line, composition, texture, colour value, chiaroscuro. Due to the thematic diversity of the drawings, in the analyses the ways of depicting the elements that follow included: a view of a house, a human figure in motion, a group of human figures; including the way of making oneself distinctly visible, the kinds of games played, the content of the fantastic drawing. All the formal and content -related qualities were noted in specially designed tables.

\section{CONCLUSIONS}

The analyses conducted in 2004 had already indicated that not only were the children willingly acquiring the electronic media content, but also applying formal means, as a result of being under media influence. The qualitative and quantitative analyses revealed that, inspired by cartoons, students often used new methods for representing a movement, or simultaneous spatial seeing stimulated by computer games. At that time, formal qualities such as texture, colour value, chiaroscuro, and line seemed to correspond more to the individual development of a child and artistic education than to the impact of the media. It is also important to mention the occurrence of elements of aggression appearing in drawings, clearly inspired by images provided by electronic media.

The research material analysed in 2014 confirmed the conclusions of 2004, and showed intrinsic changes both in the artistic form and in the content of the drawings. This had already been observed in the drawings of the kindergarten group. The extrinsic model, a standard learnt pattern, frequently distorts the drawing of a child aged 3 to 6 years, which according to the specialized literature should be based on the intrinsic model. Boys in particular seemed to be more receptive to these models, especially in the drawing of an animal (Fig. 1). The human figure scheme is less susceptible to extrinsinc models, but evenfor this topic, cartoon characters appear more and more often (Fig.3, Fig.4). Even cephalopods regarded as characteristic and universal schemes are subject to wide modifications. Moreover, acceleration of the artistic creativity crisis, appearance of lack of trust in one's own abilities, reluctance to draw, application of so-called peripheral composition were also observed (Figs. 2). It seems that children aged 3 to 6 years are rather reluctant to draw their own ideas (intrinsic model), whereas they feel more confident in drawing what they know from extrinsic models (Figs.1). 


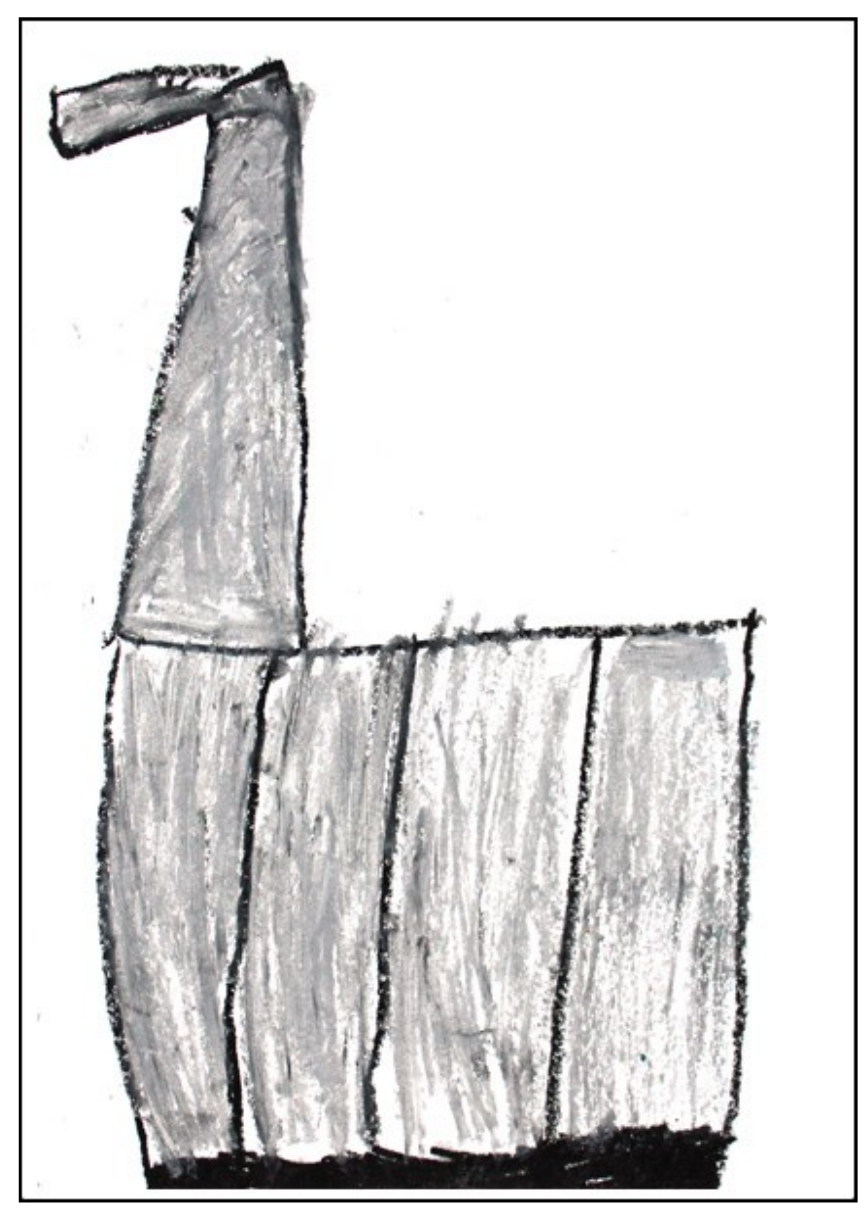

Figure 1 Wojtek 5 years - Animal (giraffe).

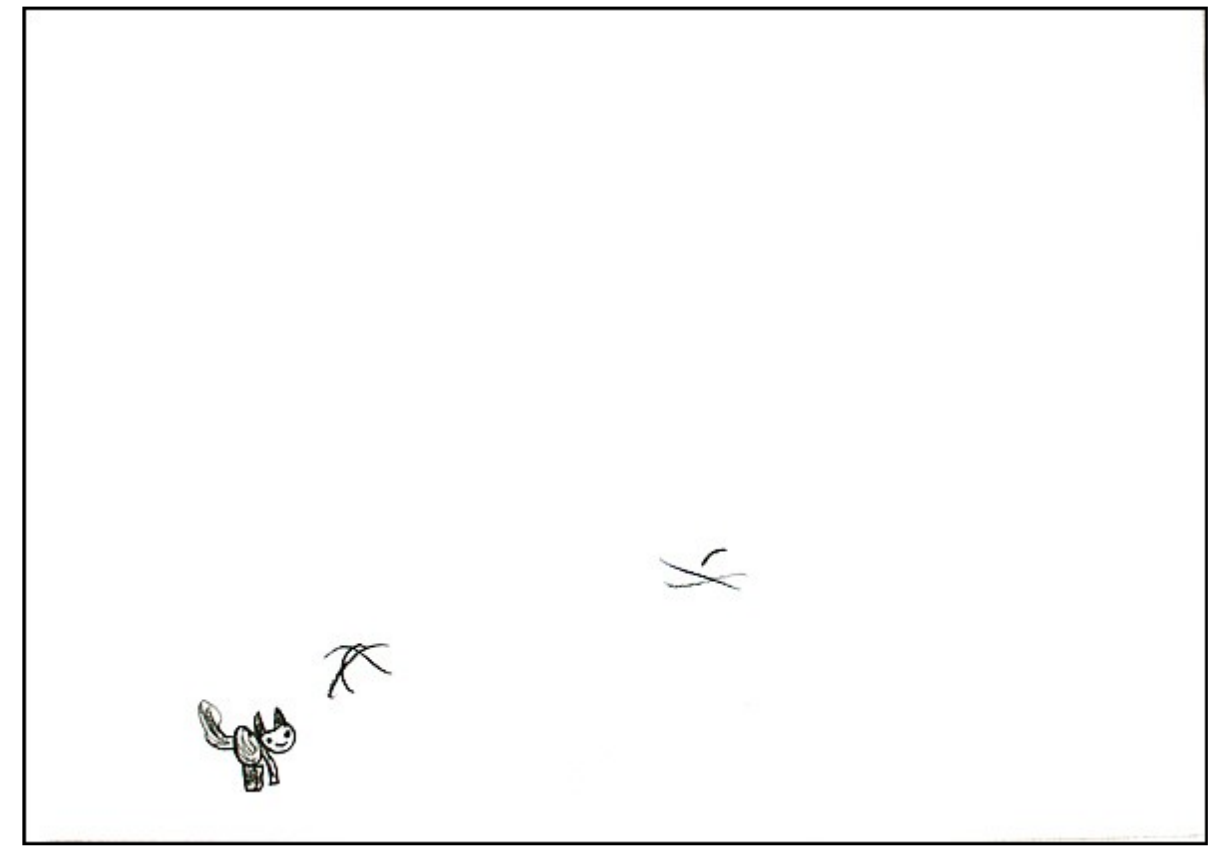

Figure 2 Michał 5 years - Animal (cat). 


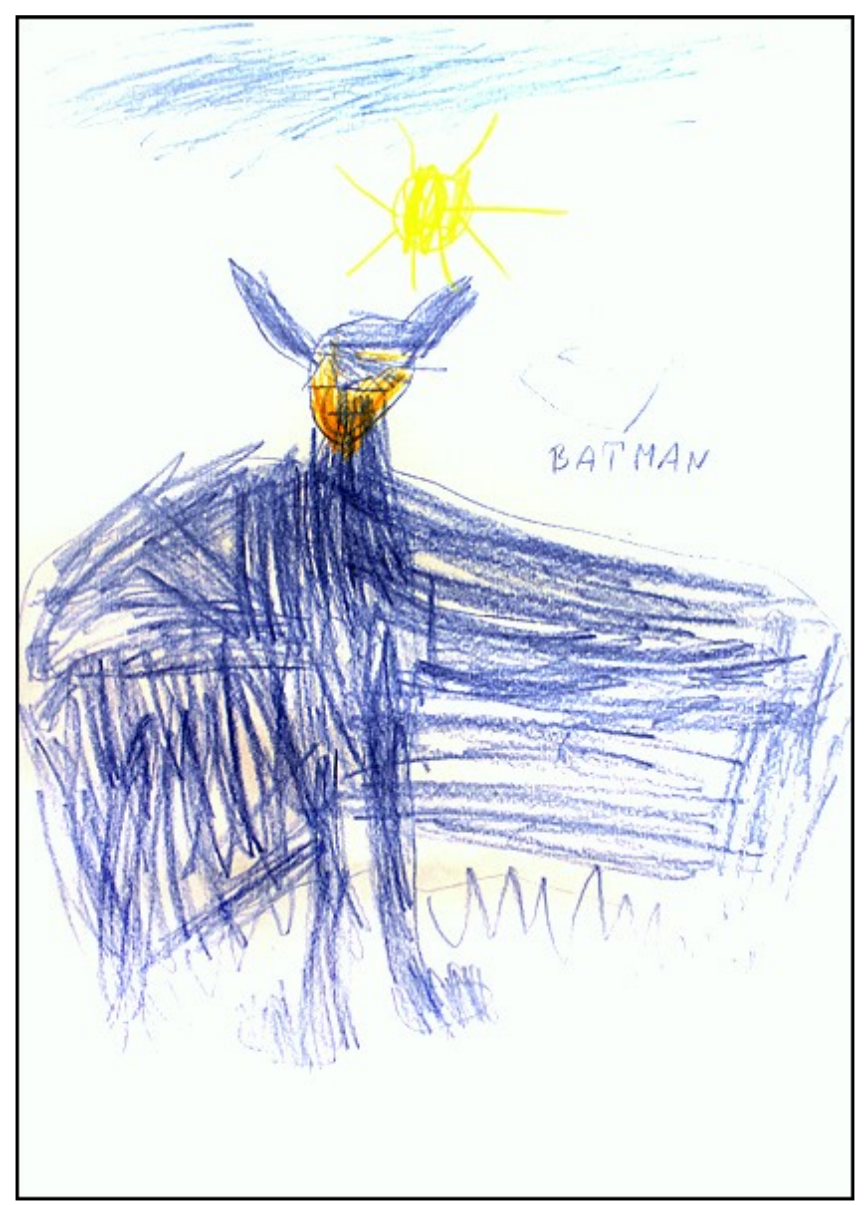

Figure 3 Kuba 5 years - Man (Batman).

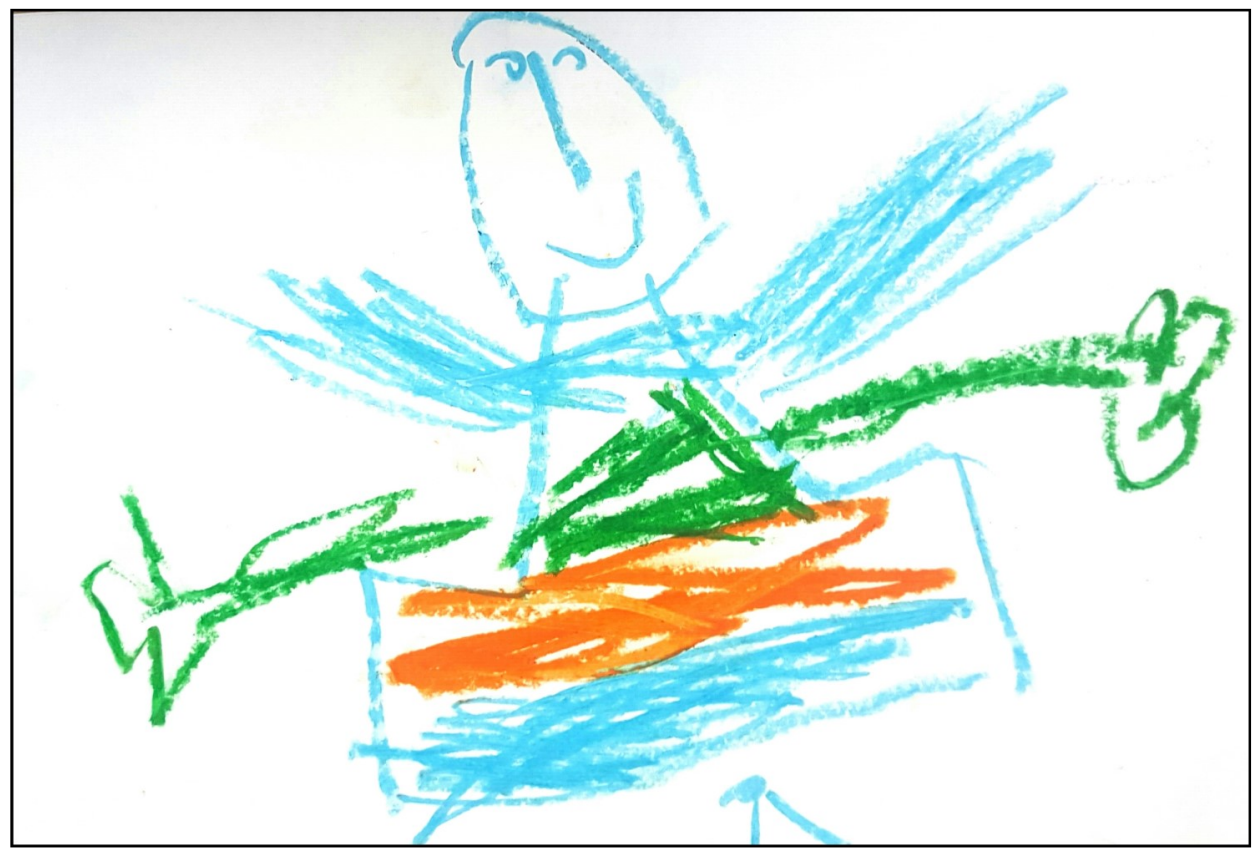

Figure 4 Jaś 5 years - Man (Superman). 
School children aged 7 to 12 years treat drawing conventions and balance between realistic and conceptual solutions rather freely and creatively, searching for an interesting artistic approach. However, most frequent are drawings referring to banal repetitions of images seen in the media. Students prefer to look for inspiration in media images rather than in reality, irrespective of the drawing topic. Therefore, fantasy figures appear among the topics in realistic world drawings such as the Drawing Task House seen from across the street (Figs. 5, 6), while in the Drawing Task Fantasy drawing from imagination, drawings showing life projections such as a beach, palm trees, swimming pool, etc. (Figs. 7, 8) are seen more and more often. The ideas are borrowed from virtual reality, which is in fact a "second-hand reality", in opposition to the real world.

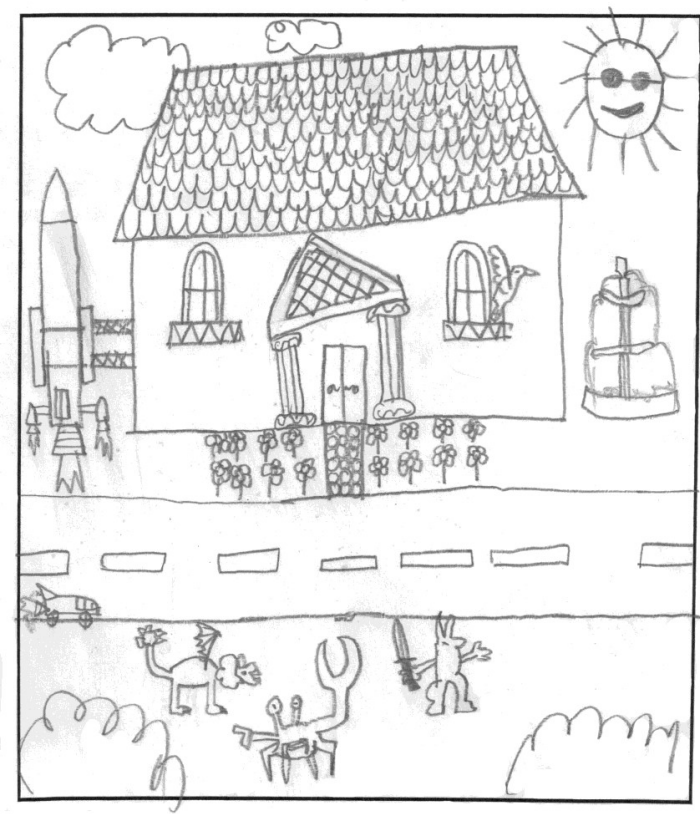

Figure 5 Kamil 10 years.

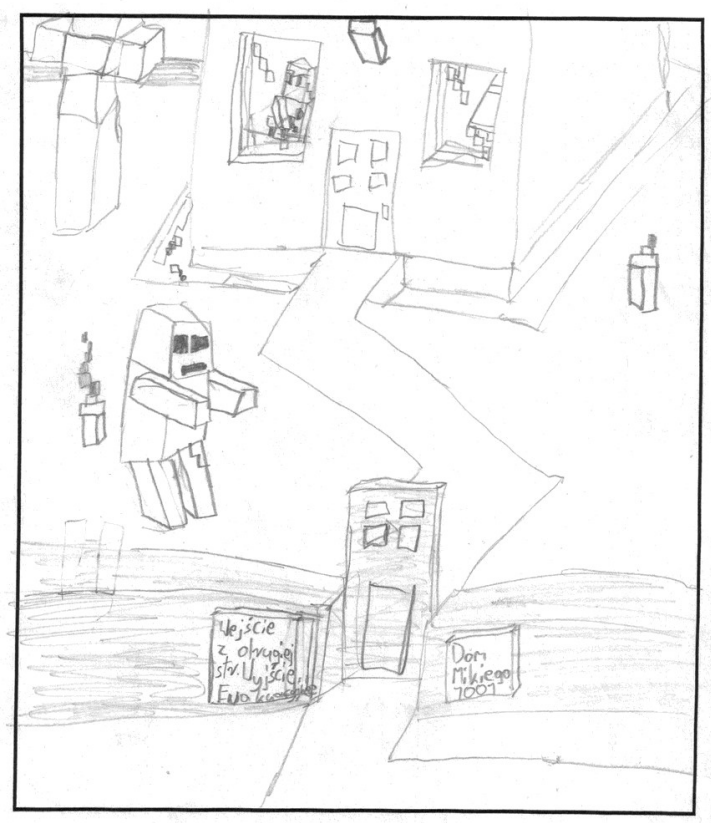

Figure 6 Mikołaj 10 years. 


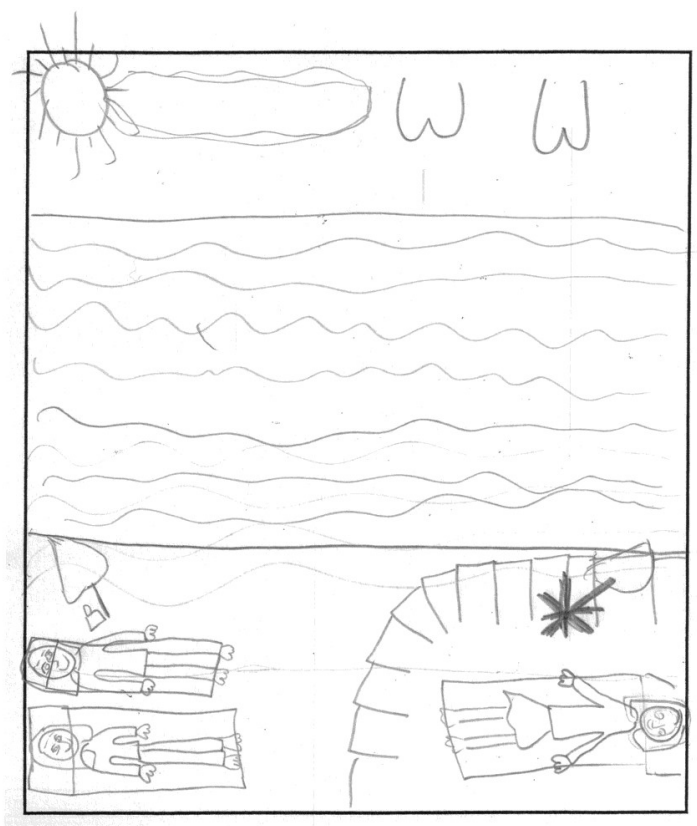

Figure 7 Oliwia 9 years.

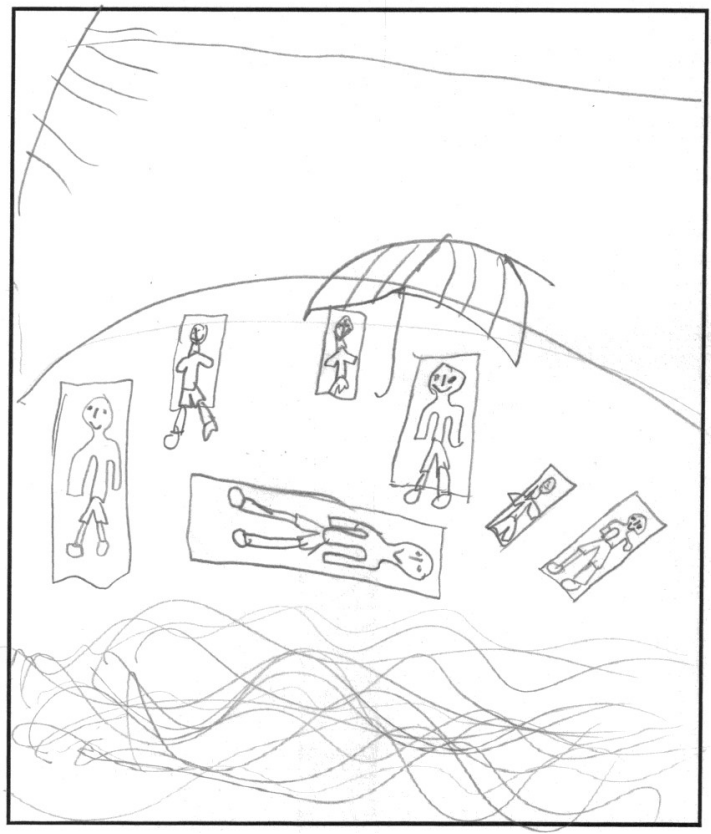

Figure 8 Julia 7 years. 
The obtained material indicates that the way of presenting spatial relations on a 2dimensional sheet of paper is related more to the topic of the drawing than to the child's age. Topographic and band perspective, even line of the base, the usage of which is usually assigned to younger children by researchers, is nowadays equally applied by children aged 7 years as well as 12 years. Children transfer formal qualities easily to their drawings. As a result, we observe interesting frames bringing to mind seeing through the eye of a camera and simultaneous spatial seeing, manifested by atypical shortcuts, greater decorativeness (Figs. 9, 10) and emphasizing the two-dimensionality of the sheet of paper (Fig. 11). "Screen" seeing is represented by the introduction of inscriptions, emoticons and "tile" icons (Figs. 11, 12).

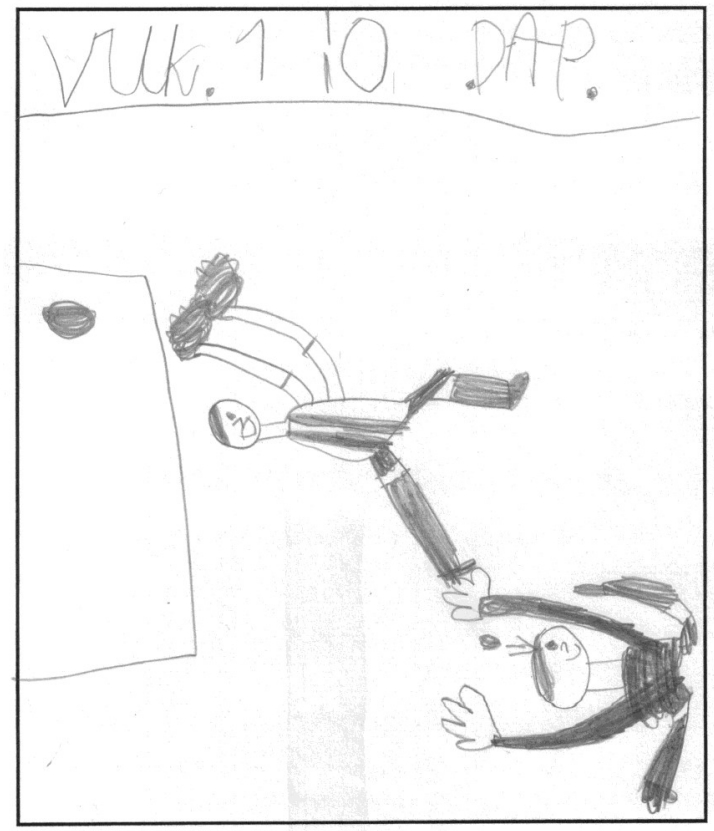

Figure 9 Albert 8 years.

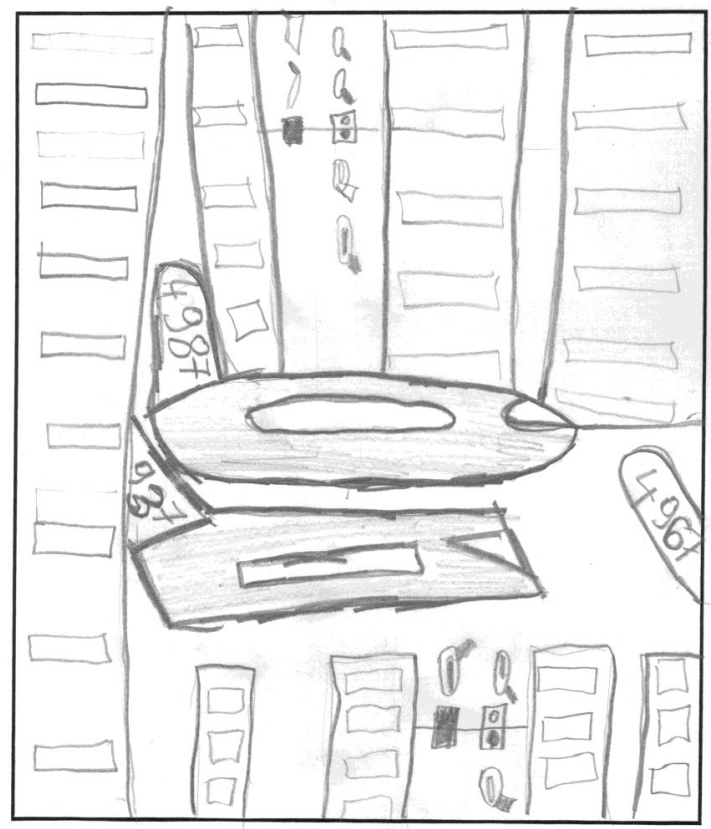

Figure 10 Tomasz 12 years. 


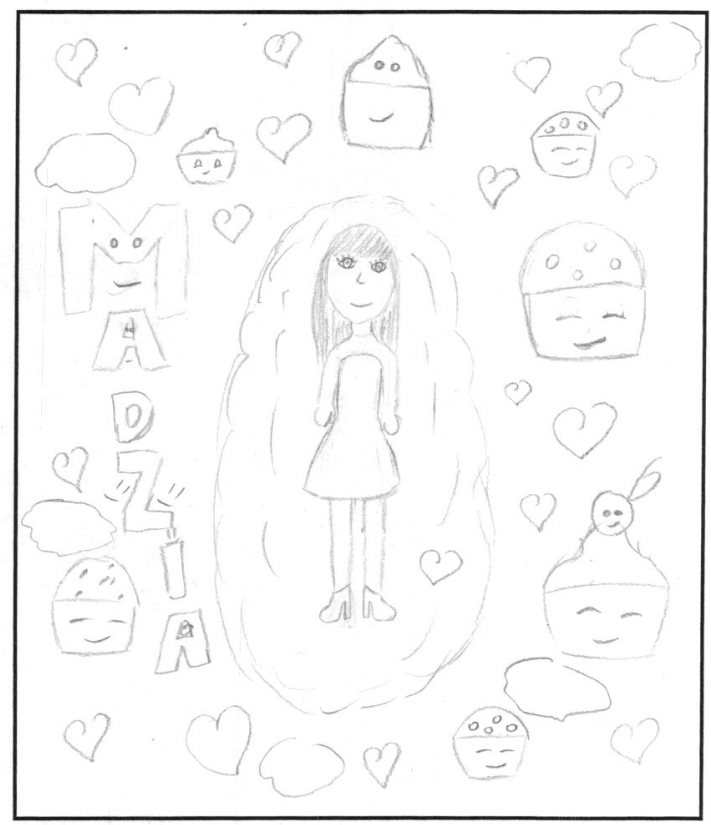

Figure 11 Magda 10 years.

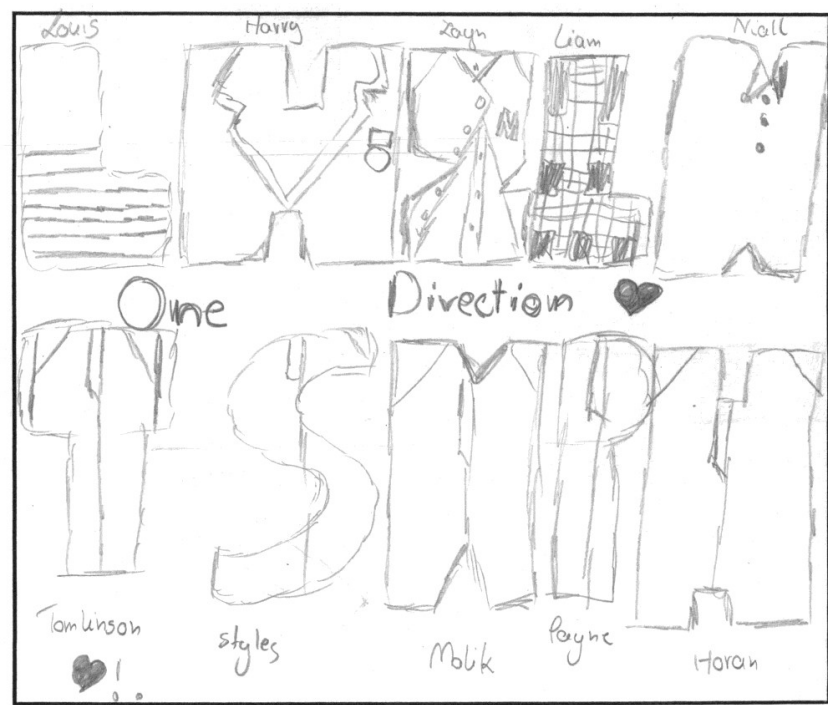

Figure 12 Kasia 12 years. 
Many students cannot or do not want or are bored with experimenting with an artistic tool, thus the linear values appearing in their drawings is trivial or reckless. However, there are also works where students play with a line and introduce tonal contrasts or sharp chiaroscuros by means of this line (Figs. 13, 14).

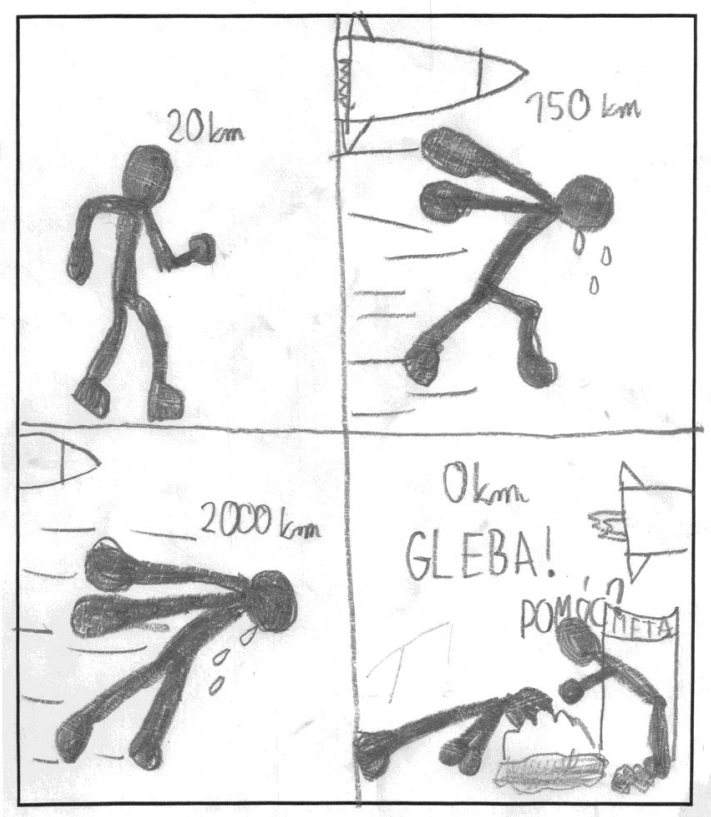

Figure 13 Wiktor 10 years.

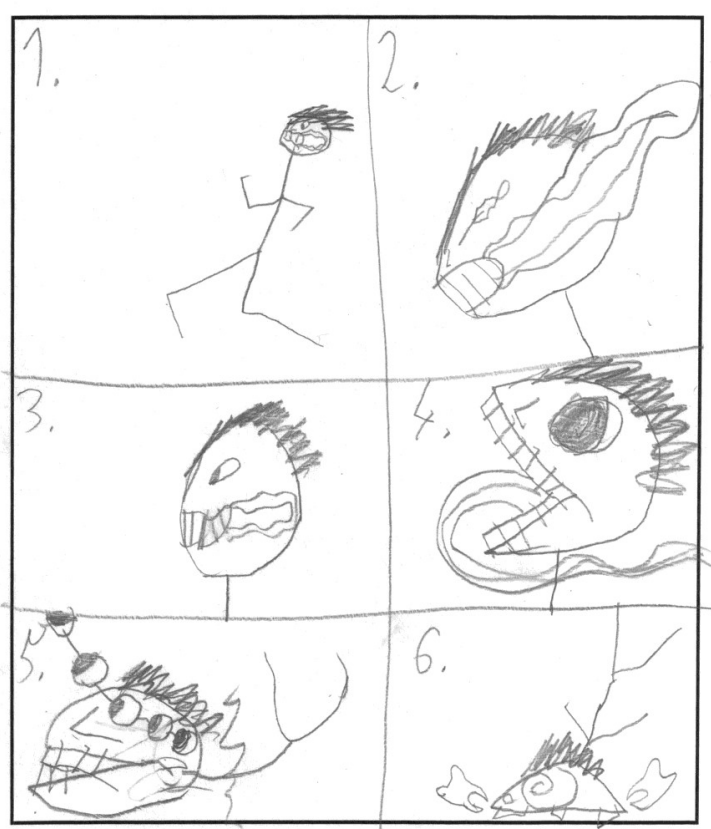

Figure 14 Radek 10 years. 
Confrontation between the child's own imagination and media representations reveals a degeneration of human figure drawing, becominga simple, even primitive symbol of a human figure or a grotesque anthropoidal vision (Figs. 15, 16). In my opinion, a low level of artistic education in kindergartens and schools may be responsible for such behaviour.

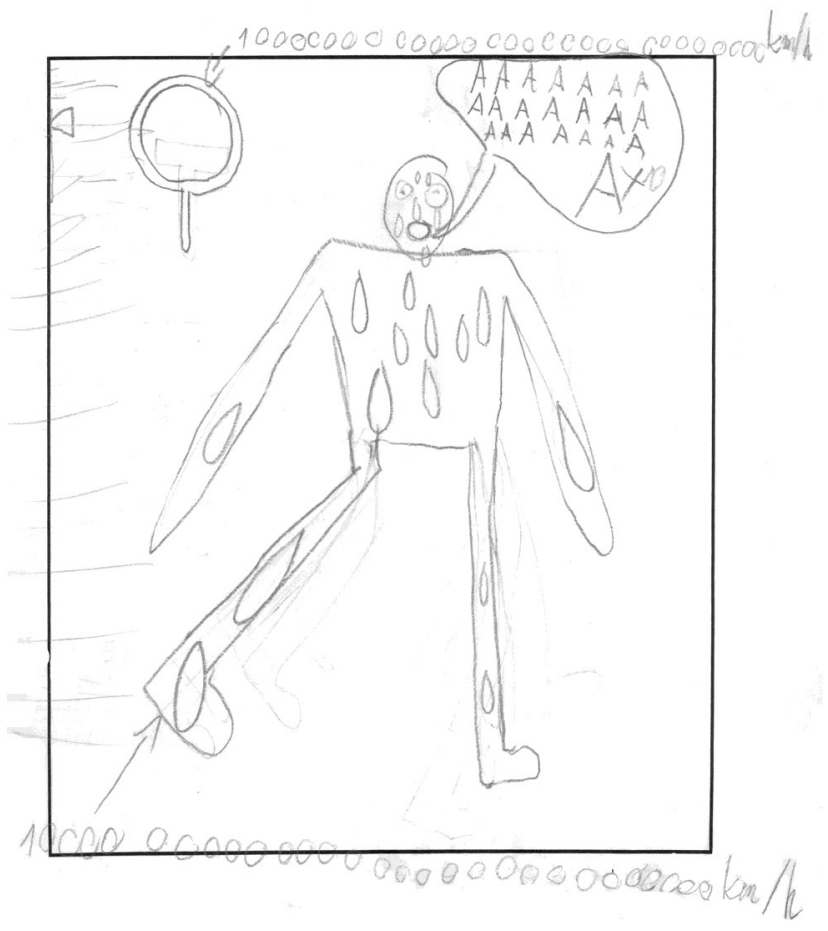

Figure 15 Kuba 10 years.

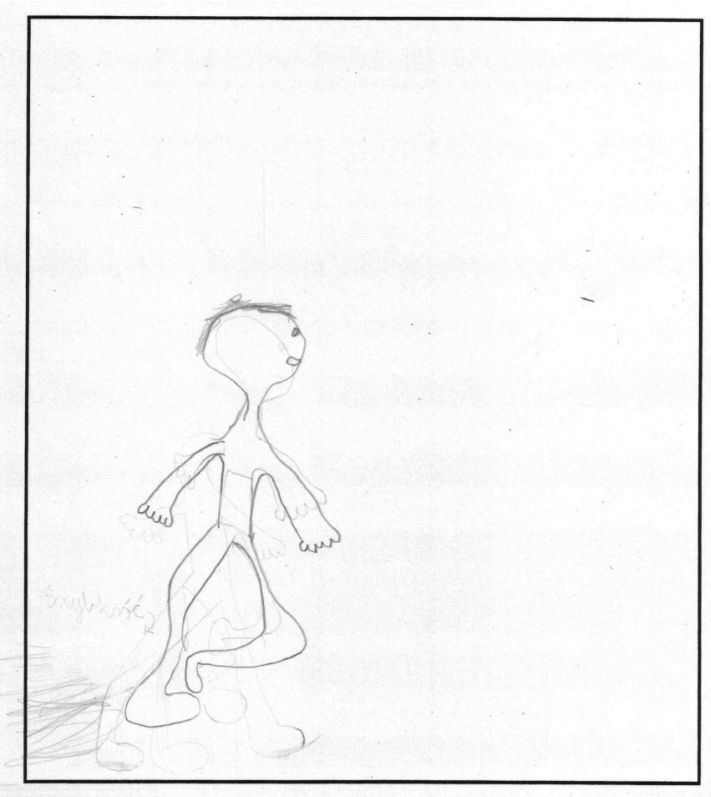

Figure 16 Paulina 8 years. 
Thus, media models may become the sources of inspiration as well as sources of setback:

- among children there were some individuals who applied media models but transformed these models in their own way,

- another group of children referred to conceptual means, e.g. speed pattern instead of a quickly running person,

- some children copied the media model with obvious manual ease, this behaviour being repeated frequently, thus integrated the model with their own drawing activity (the socalled impregnated form, see Lurçat, 1993).

\section{FINAL REMARKS}

In my research, I have stressed the significance of drawing activity for the development of a child aged 3 to 12 years, bearing in mind differences occurring between kindergarten and school groups. The search for arguments in favour of media education, directly referring to visual education, is of great importance to me. I assume that visual education is related to contemporary social and artistic events, including all modern iconospheres; it improves cognitive functions such as perception and observation capability, visual memory, divergent thinking, and furthermore, a critical and selective ability to perceive an image.

\section{REFERENCES}

Clark, G.A. (1989). Clark's drawing abilities test. Bloomington: Art. Pubishing Co.Inc.

Didkowska, B. (2004). Media elektroniczne a rysunek dzieci i młodzieży w wieku od 3 do 18 lat, unpublished doctoral dissertation.

Didkowska, B. (2015). Rysunek dziecka w wieku od 3 do 12 lat a język wizualny nowych mediów. Toruń: Wydawnictwo Naukowe UMK.

Goban-Klas, T. (2004). Niepokorna orkiestra medialna. Dyrygenci i wykonawcy polityki informacyjnej w Polsce po 1944 roku. Warszawa: Oficyna Wydawnicza Aspra-Jr.

Kościelecki, S. (1975). Współczesna koncepcja wychowania plastycznego. Warszawa: PWN.

Lurçat, L. (1993). De l'évolution graphhique a l'influence de la télévision. Journal des Psychologues, 108, 44-46.

Luquet, G.H. (1927). Dessin enfantain. Paris: Alcan.

Manovich, L. (2006). Język nowych mediów. Warszawa: Wydawnictwa Akademickie i Profesjonalne.

Popek, S. (2010). Psychologia twórczości plastycznej. Kraków: Impuls.

Szuman, S. (1927). Sztuka dziecka. Psychologia twórczości rysunkowej dziecka. War- 
szawa: Książnica-Atlas.

Szuman, S. (1990). Sztuka dziecka. Psychologia twórczości rysunkowej dziecka. Warszawa: WSiP.

Wallon, P., Cambier, A., Engelhard, D. (1993). Rysunek dziecka. Warszawa, WSiP.

Corresponding author at: Bernadeta Didkowska, Department of Art Education, Nicolaus Copernicus University, 4 Sienkiewicza St., 87-100 Toruń, Poland

E-mail: bedid@ poczta.onet.pl 